\title{
MASSIVE CRISIS ON CORONAVIRUS DISEASE (COVID-19) - AN OUTBREAK SITUATION: STAY AWARE \& BE PROTECTIVE
}

\author{
AMIT DUTTA $^{1}$, Yuvraj Mohite ${ }^{2}$, and Ravidrakumar Bakal ${ }^{3}$ \\ ${ }^{1}$ Affiliation not available \\ ${ }^{2}$ Smt. Sindhutai Jadhao Arts and Science College, Mehkar. \\ ${ }^{3}$ Dr. Rajendra Gode Institute of Pharmacy, Amravati
}

April 28, 2020

\begin{abstract}
Coronaviruses are a large group of viruses which are found in avian and mammalian species. It has been reported that, the identification and characterization of a novel coronavirus (2019-nCoV) which caused a pandemic of acute respiratory syndrome in humans in Wuhan, China. By 26 January 2020 it has caused 2,050 laboratory-confirmed infections with 56 fatal cases. Furthermore, it was found that $2019-\mathrm{nCoV}$ is $96 \%$ identical at the whole-genome level to a bat coronavirus. The new coronavirus SARS-CoV-2 binds with human respiratory cells in order to hijack them to produce more viruses. The new virus attaches to a receptor on respiratory cells called angiotensin-converting ACE2. The most abundant protein in coronavirus is the nucleocapsid protein.
\end{abstract}

\section{Hosted file}

Review Paper@ Dr. Amit Kumar Dutta.doc available at https://authorea.com/users/306975/articles/ 437987-massive-crisis-on-coronavirus-disease-covid-19-an-outbreak-situation-stay-aware-beprotective 
Kindly insert after line no 27:

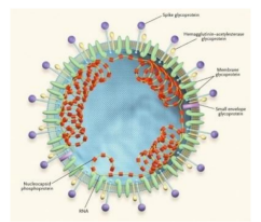

Figure: 1 The Morphology of SARS Associated Corona Virus(Zhoưadi et al, 2019)
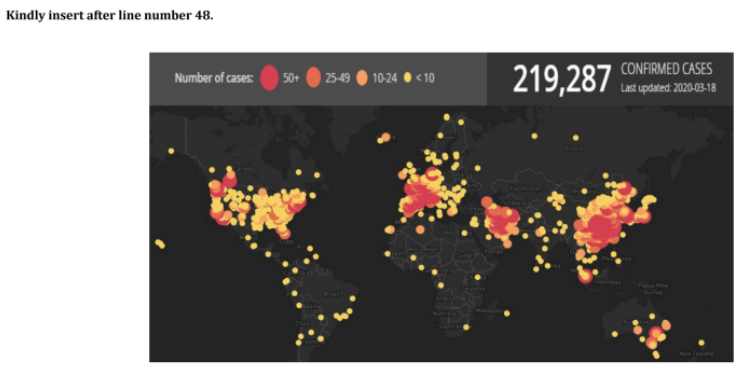

Figure 2: The Number of Corona Virus Cases Confirmed (WHO Report, 18-03-2020)

\section{Hosted file}

Figures_Corona@ Dr- Amit Kumar Dutta.pdf available at https://authorea.com/users/306975/articles/ 437987-massive-crisis-on-coronavirus-disease-covid-19-an-outbreak-situation-stay-aware-beprotective 